\title{
SPOŁECZNA ODPOWIEDZIALNOŚĆ BIZNESU W MIKROPRZEDSIĘBIORSTWACH NA PRZYKŁADZIE BRANŻY OŚRODKÓW SZKOLENIA KIEROWCÓW
}

Z a ry s tre ś c i. Współczesne rozumienie zarządzania przedsiębiorstwem nie może pomijać w swej treści koncepcji społecznej odpowiedzialności biznesu (ang. Corporate Social Responsibility), której stosowanie polega na uwzględnianiu przez przedsiębiorstwa w swoich działaniach interesów społecznych, aspektów środowiskowych oraz relacji z interesariuszami, zwłaszcza z pracownikami. Koncepcja CSR nie jest zjawiskiem nowym, mimo tego stosowana jest głównie w korporacjach, przedsiębiorstwach dużych, średnich czy małych. Mikroprzedsiębiorstwa sporadycznie wdrażają i realizują strategię społecznej odpowiedzialności biznesu, często nieświadomie stosując jej elementy. Wynika to z braku świadomości, wiedzy, czy też z obawy przed dodatkowymi kosztami. Celem niniejszego artykułu jest teoretyczne przedstawienie zagadnienia oraz uświadomienie możliwości zastosowania strategii CSR w mikrofirmach. Artykuł jest jednocześnie pierwszym z serii opracowań przedstawiających kolejne etapy wdrażania CSR w jednym z mikroprzedsiębiorstw reprezentujących branżę ośrodków szkolenia kierowców.

Słow a kluczow e: mikroprzedsiębiorstwa, społeczna odpowiedzialność biznesu, strategia, ośrodek szkolenia kierowców. 


\section{WSTĘP}

Turbulentne warunki funkcjonowania, czasy niepewności i kryzysu, zawirowań $\mathrm{w}$ polityce i gospodarce, niż demograficzny i problemy społeczne, często niejasne rozwiązania prawne czy podatkowe. Funkcjonowanie przedsiębiorstw w takiej rzeczywistości powoduje, że aby się utrzymać na rynku, należy podejmować wiele nowatorskich wyzwań, szukać nowych instrumentów konkurowania, jeszcze intensywniej wsłuchiwać się w potrzeby klienta, a nawet przewidywać jego oczekiwania. Mikroprzedsiębiorstwa, które stanowią trzon polskiej gospodarki, mają w tym względzie utrudnione zadanie, przede wszystkim z powodu nasilonej konkurencji, braku profesjonalnej kadry zarządczej, a co za tym idzie braku wiedzy w zakresie zarządzania, zwłaszcza w turbulentnych warunkach. Stąd wiele koncepcji i nowatorskich metod dotyczących zarządzania nie jest stosowanych w mikrofirmach. Jedną z nich jest koncepcja społecznej odpowiedzialności biznesu. Autorka w niniejszym artykule przedstawia zarys koncepcji i pokazuje na przykładzie konkretnej branży możliwości, jakie daje stosowanie strategii CSR, aby w kolejnych opracowaniach pokazać proces wdrażania koncepcji w jednym z mikroprzedsiębiorstw.

\section{SPOŁECZNA ODPOWIEDZIALNOŚĆ BIZNESU}

O odpowiedzialności pisał i mówił już Platon w dialogu „Gorgiasz”: „No dobrze; a cóż ta skierowana do ludu ateńskiego retoryka, albo do innego w jakimś państwie ludu, złożonego z wolnych mężów; czymże ona jest, naszym zdaniem? Czy myślisz, że mówcy zawsze przemawiają w duchu najwyższego dobra, zmierzając do tego, żeby się przez ich mowy obywatele stawali jak najlepszymi, czy też i oni wychodzą na przypodobanie się obywatelom i swoim tylko własnym dobrem zajęci nie dbają o pospolite i niby z dziećmi małymi obcując $z$ thumami, przyjemność im tylko chcąc sprawić, a czy thum przez to będzie lepszy, czy gorszy, na tym im nic nie zależy? Kalikles: To nie jest prosta rzecz to, o co się pytasz. Bo zdarzają się i tacy" (Kapias, 2011, s. 20-21). Dialog powyższy ukazuje problem odpowiedzialności za słowa, a słowa to poglądy, a poglądy z kolei rzutują na działalność człowieka. Zatem można powiedzieć, że są ludzie odpowiedzialni, kierujący się troską a są też ci, którzy za cel mają jedynie swoje dobro. Można być odpowiedzialnym za kogoś - za dziecko, za coś - za powierzone zadanie do wykonania, można być odpowiedzialnym w ogóle - za swoje czyny, za swoje decyzje. Jak więc 
dyskutować o odpowiedzialności tworu zwanego przedsiębiorstwem? Michał Kapias ukazuje trzy ujęcia, dokonując próby określenia społecznej odpowiedzialności przedsiębiorstwa.

Pierwsze - ujęcie ekonomiczne jest związane z głównym celem przedsiębiorstwa, jakim jest maksymalizacja zysków; tutaj odpowiedzialność jest traktowana jako zespół działań mających sprzyjać uzyskaniu przewagi konkurencyjnej. Drugie ujęcie, mające charakter społeczny, uwzględnia fakt istnienia przedsiębiorstwa jako jednostki funkcjonującej w społeczeństwie. „Można ową sytuację postrzegać jako zbiór zobowiązań danej organizacji, celem ochrony i umacniania społeczeństwa, w którym ona istnieje" (Fitch, 1976; Griffin, 2004, s. 144). Zdaniem autorki należy jednak polemizować $\mathrm{z}$ autorem cytatu, ponieważ można podać w wątpliwość, czy społeczeństwo faktycznie oczekuje od przedsiębiorstw ochrony, a jeśli tak, to jakiego rodzaju? Czym jest umacnianie społeczeństwa? Tego typu stwierdzenia, skoro nie odnoszą się do konkretnej grupy przedsiębiorstw, należy traktować jako prawdę ogólnie obowiązującą dla wszelkich firm. Czy więc przedsiębiorstwo usługowe ma możliwość ochrony społeczeństwa i odpowiednie ku temu narzędzia? Aby odpowiedzieć na to pytanie, należy określić pojęcie społecznej odpowiedzialności biznesu. Na stronie Ministerstwa Pracy i Polityki Socjalnej odnajdujemy taką definicję: „Społeczną odpowiedzialność biznesu określa się jako koncepcję, dzięki której przedsiębiorstwa na etapie budowania strategii dobrowolnie uwzględniają interesy społeczne i ochronę środowiska, a także relacje z różnymi grupami interesariuszy. Bycie odpowiedzialnym nie oznacza tylko spełnienia wszystkich wymogów formalnych i prawnych, ale oprócz tego zwiększone inwestycje w zasoby ludzkie, w ochronę środowiska i relacje z otoczeniem firmy, czyli dobrowolne zaangażowanie"'. Takie pojmowanie CSR bardzo zawęża możliwości realizacji koncepcji. Czy więc skoro przedsiębiorstwo uwzględnia interesy społeczne później, nie w trakcie budowania strategii czyż to nie jest społeczna odpowiedzialność? A jeśli firma nie ma strategii? Mikroprzedsiębiorstwo organizujące festyn dla dzieci, które nie ma strategii, jest również społecznie odpowiedzialne. Poza tym jak rozumieć sformułowanie: „dobrowolne”? Jeśli przytaczany jako przykład festyn jest organizowany ze względu na wcześniejsze zobowiązanie przedsiębiorstwa tudzież wynika z konkretnej umowy, jest również przykładem działania społecznie odpowiedzialnego. Nie można więc w ramach CSR stosować tego typu ram i ograniczeń, ale należy otwierać nowe drogi przedsiębiorstwom

1 Departament Pożytku Publicznego, http://www.pozytek.gov.pl/Spoleczna,odpowiedzialnosc, biznesu,464.html (19.07.2012). 
i zachęcać do działania, gdyż „to właśnie system sterowany przez polityków, jako strażników publicznych interesów, nadaje (powinien nadawać) moralny kierunek podejmowanym w przedsiębiorstwach decyzjom" (Zaorski-Sikora, 2004, s. 51). Bardziej zachęcająca definicja, jeśli w ogóle można definicje rozpatrywać w kryteriach zachęty, zawarta jest w ramach normy ISO 26000. Społeczna odpowiedzialność biznesu to: „Odpowiedzialność organizacji za wpływ jej decyzji i działań (produkty, serwis, procesy) na społeczeństwo i środowisko", przez przejrzyste i etyczne zachowanie, które:

- przyczynia się do zrównoważonego rozwoju, zdrowia i dobrobytu społeczeństwa,

- bierze pod uwagę oczekiwania interesariuszy,

- jest zgodne z obowiązującym prawem i spójne z międzynarodowymi normami zachowania,

- jest spójne z organizacją i praktykowane w jej relacjach"”.

„Społeczne odpowiedzialność jest procesem, w ramach którego przedsiębiorstwa zarządzają swoimi relacjami z różnorodnymi interesariuszami, którzy mogą mieć faktyczny wpływ na sukces w działalności gospodarczej, należy je zatem traktować jako inwestycję a nie koszt"’. Według R.W. Griffina społeczna odpowiedzialność to ,zestaw zobowiązań organizacji do ochrony i umacniania społeczeństwa, w którym funkcjonuje" (Griffin, 1998, s. 144). Natomiast grupa doradcza ISO ds. Społecznej Odpowiedzialności przyjęła następującą roboczą definicję tej koncepcji: „Zrównoważone podejście w adresowaniu ekonomicznych, społecznych i środowiskowych zagadnień w taki sposób, aby przynieść korzyść dla ludzi, społeczności i społeczeństwa"4.

W literaturze odnaleźć można wiele definicji CSR, zwracających uwagę na różne aspekty zagadnienia; wynika to $\mathrm{z}$ faktu, iż problematyka CSR jest przyczyną rozważań i dyskusji w wielu środowiskach. Zwolennicy uważają, że należy ponosić konsekwencje działalności przedsiębiorstw oraz niwelować jej negatywne skutki, natomiast przeciwnicy odpowiadają, że zajmowanie się społeczną odpowiedzialnością spowoduje skierowanie uwagi na inne cele, a nie na cel główny firmy, jakim jest osiąganie zysku ${ }^{5}$. Zdecydowany przeciwnik tej koncepcji M. Friedman uważa nawet, ,iż w przypadku świata biznesu

2 http://www.odpowiedzialnafirma.pl/o-csr/iso-26000 (19.07.2012).

3 Departament Pożytku Publicznego, http://www.pozytek.gov.pl/Spoleczna,odpowiedzialnosc,biznesu,464.html (20.07.2012).

4 Working Report on Social Responsibility, ISO Advisory Group on Social Responsibility, 30 kwietnia 2004 r., s. 27-28, [w:] j.w.

Zob. tamże, s. 16. 
ukrywanie się pod maską społecznej odpowiedzialności jest zachowaniem schizofrenicznym czy wręcz wywrotowym" (Zaorski, Sikora, 2007, s. 51). Poglądy Friedmana dotyczące prawdziwych postaw właścicieli firm krytykuje P.H. Werhahn, uważając, że „taki typ odpowiada karykaturze egocentrycznego przedsiębiorcy, opanowanego wyłącznie dążeniem do zysku, który bogaci się kosztem współpracowników i konsumentów" (Werhahn, 2003, s. 23). Przecież „człowiek poprzez swoją biologiczną konstrukcję wchodzi w dialektyczny kontakt $\mathrm{z}$ otoczeniem: $\mathrm{z}$ innymi ludźmi tworząc społeczeństwo - wspólnoty/grupy oraz środowiskiem naturalnym - ekologia”, dodaje S. Mycek (2006, s. 16). Na tle takich sporów CSR coraz bardziej się rozwija, aczkolwiek pewne normy społecznej odpowiedzialności są uwarunkowane tym, w jakim kraju zostały ustanowione, np. w Holandii za naczelne reguły uznaje się bezpośredniość, przestrzeganie praw człowieka (Gasparski, 2003, s. 46), z kolei w Szwecji mówi się o wspieraniu innych czy też o tzw. Folkhemmet - ludzkim domu, ciepłym i pełnym uczuć, a w Wielkiej Brytanii kluczowe okazuje się wzorowanie się na USA, utylitaryzm, odrzucenie karty z Maastricht (Gasparski, 2003, s. 46).

Coraz bardziej dynamicznie zwiększa się liczba firm zainteresowanych wprowadzeniem CSR do swej działalności. Jak podaje Europejska Agencja Bezpieczeństwa i Zdrowia w Pracy, „można zidentyfikować dwa podstawowe motywy wprowadzenia koncepcji odpowiedzialności społecznej: tworzenie nowych szans i lepsze kontrolowanie zagrożeń, zapewniające ciągłość funkcjonowania organizacji. Rosnące zainteresowanie CSR wywołują także ostatnie skandale związane ze złym zarządzaniem firmami" (Społeczna, 2006, s. 15). Należy mieć nadzieję, iż mimo, że etyka w biznesie napotyka na przeszkody zidentyfikowane jako czynniki organizacyjne: „konkurencja, maksymalizacja zysków, zmiany w otoczeniu transformującej się gospodarki, konflikty" (Górka red., 1999, s. 55), to jednak nadal będzie promowana jako koncepcja sprzyjająca rozwojowi przedsiębiorstw, a przedsiębiorstwa wezmą na siebie odpowiedzialność na poziomie minimalnym, „czyniąc przedmiotem swej troski klienta: wyraża się to w zaspokajaniu jego potrzeb w zakresie łatwości wykorzystania i bezpieczeństwa oferowanego produktu, środowisko, zapewnienie minimalnego standardu warunków pracy" (Pratley, 1998, s. 17). 


\section{SPOŁECZNA ODPOWIEDZIALNOŚC BIZNESU W MIKRORZEDSIĘBIORSTWACH}

Problematykę CSR, często porusza się w kontekście dużych korporacji, ewentualnie niektórych firm z sektora MŚP. Aby rozwijać ideę społecznej odpowiedzialności, należy zatem spróbować dokonać analizy możliwości realizowania jej wytycznych w mikroprzedsiębiorstwach. Przemawiają za tym ważne fakty: „Polska gospodarka opiera się na mikroprzedsiębiorstwach. Najmniejszych polskich firm jest niespełna 3,5 miliona, z czego działa połowa. Mikroprzedsiębiorstwa stanowią ok. 93 proc. podmiotów gospodarczych w Polsce. Wśród nich ponad milion stanowią »jednoosobowi przedsiębiorcy«. Przez przedsiębiorstwo mikro rozumiemy przedsiębiorstwo zatrudniające nie więcej niż 10 osób i mające przychód netto poniżej $2 \mathrm{mln}$ euro lub sumę aktywów w bilansie rocznym poniżej $2 \mathrm{mln}$ euro". . To bardzo istotna dla gospodarki grupa firm, często pomijana w opracowaniach dotyczących kwestii związanych z zarządzaniem lub omawiana wraz z pozostałymi przedsiębiorstwami z sektora MŚP: małymi i średnimi, co nieco zniekształca ogólny obraz sektora. Rola mikroprzedsiębiorstw w gospodarce kraju czy też poszczególnych regionów nie tkwi tylko i wyłącznie w liczbie mikrofirm, ale też w specyfice funkcjonowania tego rodzaju przedsiębiorstw. Jako przykład można tu przytoczyć chociażby wypełnianie luki rynkowej w przypadku, gdy działanie dużych firm jest nieopłacalne; dotyczy to głównie sektora usług, umiejętności dostosowania się do zmian na rynku przez modyfikację swojej oferty czy też zmianę branży. Mikroprzedsiębiorstwa tworzą nowe miejsca pracy, zatrudniając często pracowników, którzy często ze względu na kryteria oceny stosowane podczas rekrutacji nie mają szans na zatrudnienie w dużych przedsiębiorstwach. Budowanie lojalności klienta, możliwość bezpośredniego kontaktu właściciela z klientem pozwalająca na uzyskanie informacji o jego oczekiwaniach, uwagach czy też zastrzeżeniach pozwala na bieżące kontrolowanie poziomu satysfakcji czy też niezadowolenia ostatecznego nabywcy, a także daje możliwości dostosowania oferty do zmieniających się potrzeb rynku i budowania nowych instrumentów konkurowania. Mikroprzedsiębiorstwa, wykorzystując swój potencjał, mogą dodatkowo czerpać rozwiązania stosowane przez duże firmy i modyfikować je w sposób pozwalający na efektywne ich zastosowanie w praktyce. Jednym $\mathrm{z}$ takich rozwiązań jest właśnie koncepcja społecznej odpowiedzialności biznesu.

6 Pentor, http://www.pentor.pl/36526.xml?doc_id=11280 (23.07.2012). 
Wiele mikrofirm realizuje, często nieświadomie, działania społeczne wpisujące się w koncepcję społecznej odpowiedzialności biznesu, które nie są elementem strategii przedsiębiorstwa czy też jego polityki. Świadczy to o tym, że tego typu realizacje nie muszą oznaczać ogromnych nakładów finansowych, a wręcz przeciwnie - działania związane z CSR mogą oznaczać zmniejszenie nakładów i wzrost zysku finansowego. Przykłady takich działań to: wdrażanie ekologicznych procesów technologicznych, elastyczne formy zatrudnienia, zatrudnianie osób wykluczonych społecznie czy zagrożonych bezrobociem, terminowe wypłacanie wynagrodzeń, bezpieczeństwo pracy, eko-znakowanie produktów, racjonalne gospodarowanie odpadami i zasobami naturalnymi. Zatem można, opierając się na śladach takich działań, podjąć próbę stworzenia procesu mającego na celu systematyczne wdrażanie strategii CSR w mikroprzedsiębiorstwach. Bardzo ciekawym projektem skierowanym do sektora MŚP jest realizowana na zlecenie Polskiej Agencji Rozwoju Przedsiębiorczości usługa pod nazwą: „Zwiększenie konkurencyjności regionów poprzez społeczną odpowiedzialność biznesu". Projekt jest finansowany przez Szwajcarię w ramach szwajcarskiego programu współpracy z nowymi krajami członkowskimi Unii Europejskiej. W ramach projektu zaproponowano mikroprzedsiębiorcom wdrażanie strategii CSR, opierając się na modelu Deminga: PLAN-DO-CHECK-ACT ${ }^{7}$. Pierwszym etapem wdrażania strategii będzie zatem określenie, czym dla danej branży i dla danego przedsiębiorstwa jest CSR i jakie praktyki z punktu widzenia interesariuszy będą odpowiedzialne.

\section{OŚRODKI SZKOLENIA KIEROWCÓW}

Jedną z charakterystycznych grup mikroprzedsiębiorstw są firmy reprezentujące branżę ośrodków szkolenia kierowców. To branża dynamicznie się rozwijająca, lecz dynamika ta ma swoje uwarunkowania i stwarza pewne pozory rozwoju, co czyni ją odmienną od innych. Wynika to z faktów, iż osoby nieposiadające przygotowania ani wiedzy w zarządzaniu, zakładając własne ośrodki szkolenia kierowców zwane również w dalszej części pracy szkołami jazdy, nie biorą pod uwagę wielu uwarunkowań mających wpływ na rozwój firmy czy też na jej upadek, co często tymże upadkiem się właśnie

7 Informacje pochodzą $\mathrm{z}$ materiałów szkoleniowych PARP przeznaczonych dla uczestników spotkania informacyjnego na temat społecznej odowiedzialności biznesu organizowanego w ramach cytowanego projektu - dzień 2, s. 7. 
kończy ${ }^{8}$. Firmy, które pozostają na rynku i zajmują się działalnością priorytetową w branży, a więc szkoleniem kandydatów na kierowców, mają jednak do spełnienia nie tylko obowiązek wynikający z narzucanych im przepisów, ale także misję wynikającą z charakteru działalności. Statystyki bowiem są zatrważające. „Mamy pierwsze - najgorsze - miejsce w Unii Europejskiej pod względem liczby śmiertelnych ofiar wypadków drogowych w 2011 r., wynika z danych Komisji Europejskiej, na które powołuje się »Gazeta Wyborcza«. Jeszcze w 2010 r. w tej statystyce wyprzedzały nas Rumunia, Grecja i Bułgaria. W całej Unii w ciągu dziesięciu lat wskaźnik śmiertelnych wypadków na drogach spadł o 43\% (dzięki temu żyje 125 tys. osób), ale w Polsce już tylko o 29\%". Ten stan rzeczy wynika m.in. z takich czynników, jak jakość dróg, zbyt mało restrykcyjne sankcje za niektóre wykroczenia, zwłaszcza jazda po alkoholu, ale także błędy w szkoleniu i egzaminowaniu, u podstaw których leży również cała masa błędów po stronie ustawodawcy. Jednak działalność szkół jazdy prowadzona z głównym zamysłem - osiągania zysku - powinna również mieć cechy biznesu społecznie odpowiedzialnego, co ma swoje uzasadnienie. Szczególnym przesłaniem, misją branży winno być wykształcenie u przyszłych użytkowników dróg postaw mających wpływ na bezpieczeństwo własne i innych kierowców. W żadnej innej branży nie występuje tego rodzaju kształtowanie nawyków, umiejętności, zachowań. Dlatego też, aby mówić o społecznej odpowiedzialności biznesu w takiej działalności jak ośrodek szkolenia kierowców, nie wystarczy stosować ogólnie przyjętych pojęć. W opisywanej branży istnieje kilka obszarów nakładających się na siebie w trakcie szkolenia. Są to:

- odpowiedzialność za otoczenie, w którym firma funkcjonuje,

- odpowiedzialność za przekazywaną wiedzę, umiejętności, postawy,

- odpowiedzialność za wykształcenie określonego stopnia świadomości związanego z wyuczonymi nawykami.

Aby określić możliwości oddziaływania, należy zidentyfikować, kim są interesariusze ośrodków szkolenia kierowców. Interesariusze, a więc osoby, instytucje, organizacje pozostające we wzajemnych interakcjach z organizacją. W encyklopedii zarządzania znajdujemy definicję wskazującą na aktywny charakter interesariuszy: interesariusze (ang. stakeholders) - są to osoby lub inne organizacje, które uczestniczą w tworzeniu projektu (biorą czynny udział w jego realizacji) lub są bezpośrednio zainteresowane wynikami jego wdroże-

8 Wyniki badań własnych autorki.

9 Onet, http://wiadomosci.onet.pl/kraj/niepokojace-dane-w-polsce-najwiecejsmiertelnych-o, 1,5076732,wiadomosc.html (10.08.2012). 
nia. Interesariusze mogą wywierać wpływ na daną organizację ${ }^{10}$. W literaturze przedmiotu nie definiowano interesariuszy ośrodków szkolenia kierowców, stąd też autorka w ramach pierwszego etapu wdrażania strategii CSR dokonała samodzielnej analizy otoczenia, jednocześnie identyfikując interesariuszy występujących w branży:

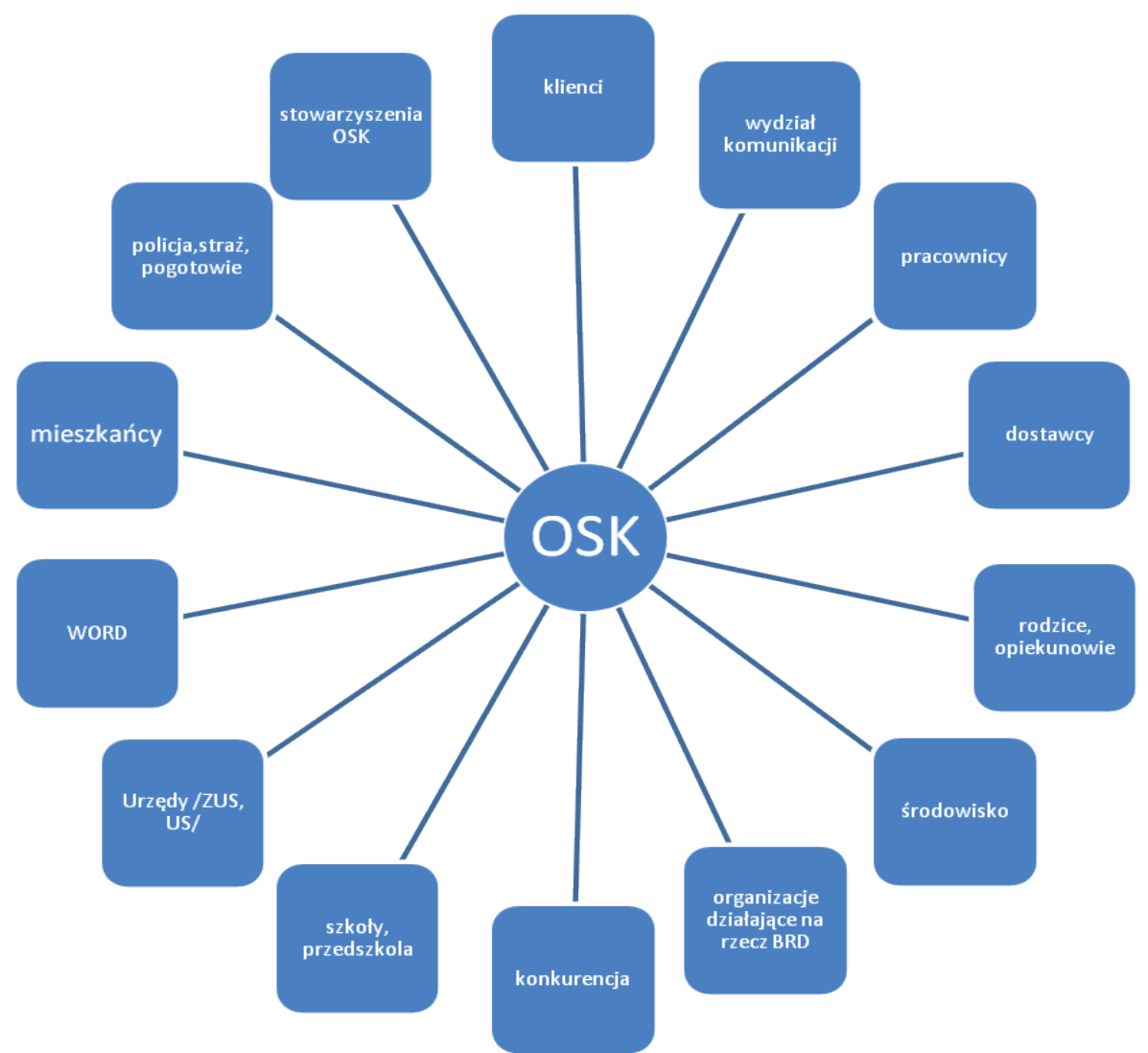

Rysunek 1. Wykaz interesariuszy występujących w branży OSK

Źródło: opracowanie własne.

Schemat pokazuje, jak wielu interesariuszy znajduje się w obszarze działania, pozostaje w pośredniej lub bezpośredniej zależności z firmą, ma wobec organizacji oczekiwania lub żądania spełnienia określonych przepisami

10 Encyklopedia Zarządzania, //www.mfiles. pl/pl/index.php/Interesariusze (23.08.2012). 
wymagań. Zatem właściciel ośrodka szkolenia kierowców winien mieć pełną świadomość powyższych zależności i ustalić taki harmonogram działań, który przyczyni się do zaspokojenia potrzeb interesariuszy, a jednocześnie pozwoli osiągać korzyści. Takie postrzeganie z jednej strony roli interesariuszy, a z drugiej niewykorzystanych możliwości pozwala na aktywizację idei CSR w przedsiębiorstwie. Aby dokonać takiego mapowania, należy oczywiście zidentyfikować zakres możliwych działań na płaszczyźnie firma-otoczenie, rozumiejąc w tym konkretnym przypadku otoczenie jako zbiór interesariuszy. Poniższa tabela pokazuje wykaz obszarów, które mogą być źródłem inicjatywy dla określonych działań:

Tabela 1. Plan działań

\begin{tabular}{|l|l|}
\hline \multicolumn{1}{|c|}{ Interesariusz } & \multicolumn{1}{c|}{ Obszar działania } \\
\hline Klienci & $\begin{array}{l}\text { etyczne postępowanie, uczciwe przekazywanie pełnej infor- } \\
\text { macji dotyczacej oferty firmy, realizacja procesu szkolenia } \\
\text { zgodnie z przepisami prawa i ustalonymi zasadami, reali- } \\
\text { zowanie oczekiwań klientów w ramach przyjętych norm } \\
\text { i zasad, wolontariat pracowniczy - na usługi klientów }\end{array}$ \\
\hline Wydział komunikacji & $\begin{array}{l}\text { postępowanie zgodnie z ustalonymi zasadami, terminowe } \\
\text { przekazywanie informacji, udział w projektach i szkoleniach } \\
\text { organizowanych przez starostwa, respektowanie wytycz- } \\
\text { nych ustalonych przez urząd }\end{array}$ \\
\hline Pracownicy & $\begin{array}{l}\text { komfortowe, bezpieczne, higieniczne warunki pracy, pro- } \\
\text { mocja zdrowia, programy redukujące stres, zapewnienie po- } \\
\text { mocy psychologicznej, profilaktyka wypalenia zawodowego, } \\
\text { stworzenie elastycznego czasu pracy, urlopy tacierzyńskie, } \\
\text { work life balance, stosowanie systemów motywacyjnych, } \\
\text { regularne wypłacanie wynagrodzeń, zarządzanie talentami }\end{array}$ \\
\hline Dostawcy & $\begin{array}{l}\text { współpraca zgodna z zasadami etyki, organizowanie } \\
\text { wspólnych przedsięwzięć, zakup artykułów wytworzonych } \\
\text { z materiałów ekologicznych }\end{array}$ \\
\hline $\begin{array}{l}\text { Rodzice, opieku- } \\
\text { nowie małoletnich } \\
\text { klientów }\end{array}$ & $\begin{array}{l}\text { akcje związane z bezpieczeństwem, angażowanie rodziców } \\
\text { i opiekunów do wspólnych przedsięwzięć, organizowanie } \\
\text { spotkań edukacyjnych dla dorosłych, informowanie o prak- } \\
\text { tykach związanych np. z ochroną środowiska możliwych do } \\
\text { zastosowania w gospodarstwie domowym, np. segregacja } \\
\text { odpadów }\end{array}$ \\
\hline
\end{tabular}


Cd. tabeli 1

\begin{tabular}{|c|c|}
\hline Interesariusz & Obszar działania \\
\hline Środowisko & $\begin{array}{l}\text { propagowanie eko-jazdy, zakup materiałów szkoleniowych } \\
\text { i druków na papierze ekologicznym, kosze do segregacji } \\
\text { odpadów, analiza możliwości ograniczenia korzystania ze } \\
\text { sprzętu biurowego, ograniczenie druku - np. e-maili, ogra- } \\
\text { niczenie korzystania z transportu, informacja proekologiczna } \\
\text { dla partnerów biznesowych }\end{array}$ \\
\hline $\begin{array}{l}\text { Organizacje } \\
\text { działające } \\
\text { na rzecz } \\
\text { Bezpieczeństwa } \\
\text { Ruchu Drogowego }\end{array}$ & $\begin{array}{l}\text { czynne uczestnictwo w akcjach społecznych, współpraca } \\
\text { w zakresie wspólnych opracowań edukacyjnych, planowanie } \\
\text { działań w zakresie BRD, identyfikacja zagrożeń, tworze- } \\
\text { nie partnerstw tymczasowych - związanych z projektem } \\
\text { i stałych }\end{array}$ \\
\hline Konkurencja & $\begin{array}{l}\text { etyczne działania konkurencyjne, które nie szkalują, stoso- } \\
\text { wanie uczciwej reklamy, współpraca w ponadbiznesowych } \\
\text { przedsięwzięciach }\end{array}$ \\
\hline Szkoły, przedszkola & $\begin{array}{l}\text { organizowanie możliwych akcji typu: organizacja egzaminów } \\
\text { na kartę rowerową, motorowerową, organizowanie kon- } \\
\text { kursów, pokazy szkolenia w OSK, zainteresowanie uczniów } \\
\text { tematyką BRD }\end{array}$ \\
\hline $\begin{array}{l}\text { Urzędy: ZUS, US, } \\
\text { Inspekcja } \\
\text { Pracy }\end{array}$ & $\begin{array}{l}\text { wywiązywanie się z zobowiązań wobec urzędów, zatem } \\
\text { regularne i terminowe płacenie należności, etyczna współ- } \\
\text { praca, reagowanie na pisma, udzielanie informacji, udostęp- } \\
\text { nianie koniecznych danych }\end{array}$ \\
\hline $\begin{array}{l}\text { Wojewódzki } \\
\text { Ośrodek } \\
\text { Ruchu Drogowego }\end{array}$ & $\begin{array}{l}\text { wspólne akcje promujące bezpieczeństwo w mieście i regio- } \\
\text { nie, wymiana doświadczeń, analiza błędów na egzaminach } \\
\text { w celu zwiększenia zdawalności, a w konsekwencji bezpie- } \\
\text { czeństwa na drogach }\end{array}$ \\
\hline Mieszkańcy & $\begin{array}{l}\text { udział w festynach, rozmowy z mieszkańcami podczas } \\
\text { zebrań osiedlowych, organizowanie akcji uświadamiających } \\
\text { zagrożenia, tworzenie tzw. czarnych punktów na osiedlu, } \\
\text { profilaktyka zagrożeń }\end{array}$ \\
\hline $\begin{array}{l}\text { Policja,straż, } \\
\text { pogotowie }\end{array}$ & $\begin{array}{l}\text { wspólne organizowanie pokazów z zakresu pierwszej pomo- } \\
\text { cy, reagowania w przypadkach zagrożenia, planowanie akcji } \\
\text { zmniejszających demoralizację młodzieży, np. angażowanie } \\
\text { młodzieży do wspólnych akcji }\end{array}$ \\
\hline
\end{tabular}


Cd. tabeli 1

\begin{tabular}{|c|l|}
\hline \multicolumn{1}{|c|}{ Interesariusz } & \multicolumn{1}{c|}{ Obszar działania } \\
\hline Stowarzyszenia OSK & $\begin{array}{l}\text { opracowywanie rozwiązań mających na celu ustanowienie } \\
\text { zapisu w ustawie nakazującego stosowanie przez OSK } \\
\text { zasad CSR w związku z możliwościąami, jakie mają stowa- } \\
\text { rzyszenia w zakresie zgłaszania do ministerstwa własnych } \\
\text { sugestii, organizowanie wspólnych akcji typu: „trzeźwość na } \\
\text { drodze”, ,bezpieczny powrót do domu”, ,jestem widoczny”, } \\
\text { propagowanie etycznych zachowań instruktorów podczas } \\
\text { procesu szkolenia }\end{array}$ \\
\hline
\end{tabular}

Źródło: opracowanie własne.

Reasumując powyższe analizy, trudno się nie zgodzić z teorią mówiącą „przede wszystkim nie ma celów przedsiębiorstw, lecz jedynie cele ludzi” (Kietliński, Reyes, Oleksyn, 2005, s. 243) - cele ludzi rozumiane w bardzo szerokim znaczeniu, a więc cele środowiska, w którym funkcjonuje społeczeństwo, cele człowieka zważywszy na wiele ról, jakie pełni w społeczeństwie: rola pracownika, pracodawcy, klienta, dostawcy, mieszkańca osiedla, zatem interesariusza. Społeczna odpowiedzialność biznesu rozumiana jako stosowanie zrównoważonego biznesu, umiejętność osiągania zadowalającego zysku jednocześnie z działaniami mającymi wpływ na społeczeństwo, środowisko i pracowników to działalność bogatsza o nowe możliwości marketingowe, poznawcze. Organizacja będąca ośrodkiem szkolenia kierowców, stosująca zasady CSR stanowi bardzo ważny element lokalnej społeczności. Mieszkańcy powiedzą o firmie: ,jest jedną z nas”, „utożsamiamy się”, „chcemy być uczeni, szkoleni przez odpowiedzialnych ludzi”. Dlatego należy szeroko promować ideę CSR w mikroprzedsiębiorstwach, które są najbardziej rozpoznawanymi firmami w małych lokalnych społecznościach. Należy wprowadzać nowe rozwiązania, łączyć koncepcje ze sobą dotyczące zarządzania i dostosowywać do potrzeb i specyfiki mikroprzedsiębiorstwa. Poza tym mikrofirma może za pomocą narzędzi CSR takich jak kampanie społeczne, programy dla pracowników, działania proekologiczne, działania na rzecz społeczności lokalnej budować swoją przewagę konkurencyjną, nie przeznaczając na ten cel ogromnych nakładów finansowych. Należy zatem wierzyć, iż idea CSR $\mathrm{w}$ mikroprzedsiębiorstwach będzie propagowana, tematyka podnoszona w publikacjach naukowych, a badania i proponowane rozwiązania wdrożone w mikroprzedsiębiorstwach nie tylko pozwolą na ich rozwój, ale także po- 
każą nowe możliwość dla innych, większych firm. Jednocześnie autorka ma nadzieję, że artykuł wzbudzi zainteresowanie wynikami dalszych prac nad procesem wdrażania CSR w mikroprzedsiębiorstwach.

\section{PODSUMOWANIE}

Artykuł przedstawia ogólne zagadnienia teoretyczne obejmujące problematykę CSR w kontekście możliwości zastosowania koncepcji w mikroprzedsiębiorstwach. Autorka dokonała charakterystyki branży ośrodków szkolenia kierowców i zidentyfikowała interesariuszy oraz przedstawiła ogólny plan możliwych działań. W kolejnym artykule, kontynuującym tematykę, zostaną przedstawione wyniki badań, które obejmą ocenę istotności poszczególnych obszarów CSR dla branży, oraz wnioski wypływające z rozmów i spotkań przeprowadzonych z interesariuszami.

\section{LITERATURA}

Gasparski W. (2003), Europejskie standardy etyki i społecznej odpowiedzialności biznesu, WSPiZ im. Koźmińskiego, Warszawa.

Górka K. (red.) (1999), Etyka zawodowa w biznesie, Wydawnictwo Naukowe WSB w Bielsku-Białej, Bielsko-Biała.

Hąbek P., Szewczyk P. (2010), Społeczna odpowiedzialność a zarządzanie jakościa, Wydawnictwo Politechniki Śląskiej, Gliwice.

Kietliński K.,V. M. Reyes, T. Oleksyn (2005), Etyka w biznesie i zarządzaniu, Oficyna Ekonomiczna, Kraków, s. 243.

Polok G. (2011), Spoleczna odpowiedzialność - aspekty teoretyczne i praktyczne, Wydawnictwo Uniwersytetu Ekonomicznego, Katowice.

Mycek S. (2006), Człowiek i odpowiedzialność, Wydawnictwo Diecezjalne, Sandomierz.

Platon (1956), Gorgiasz, przeł. W. Witwicki, Warszawa.

Pratley P. (1998), Etyka w biznesie, Gebethner\&Ska, Warszawa.

Społeczna odpowiedzialność biznesu a bezpieczeństwo i higiena pracy, (2006), Europejska Agencja Bezpieczeństwa i Zdrowia w Pracy, Luksemburg.

Werhahn P.H. (2003), Przedsiębiorca, Wydawnictwo Fundacji ATK, Warszawa.

Zaorski-Sikora Ł. (2007), Etyka w biznesie, Wydawnictwo Wyższej Szkoły Humanistyczno-Ekonomicznej w Łodzi, Łódź. 


\title{
ŹRÓDŁA INTERNETOWE
}

http://www.pozytek.gov.pl/Spoleczna,odpowiedzialnosc,biznesu,464.html http://www.odpowiedzialnafirma.pl/o-csr/iso-26000 http://www.pentor.pl/36526.xml?doc_id=11280 http://wiadomosci.onet.pl/kraj/niepokojace-dane-w-polsce-najwiecej-smiertelnycho,1,5076732,wiadomosc.html http://mfiles. pl/pl/index.php/Interesariusze

\section{CORPORATE SOCIAL RESPONSIBILITY IN MICRO-ENTERPRISES FOR EXAMPLE THE SECTOR DRIVER TRAINING CENTER}

\begin{abstract}
A bstract. This article presents the corporate social responsibility and the possibility to apply the concept in micro-enterprises. This article is also the first of a series of studies showing the next stages in the implementation of CSR in the one of the microenterprises representing sector training centres of the drivers.
\end{abstract}

K e y w ord s: micro-enterprises, corporate social responsibility, strategy, driver training center. 